\title{
Metabolism of carbohydrates by rumen bacteria
}

\author{
By B. H. Howard, Rowett Research Institute, Bucksburn, Aberdeen
}

\section{Techniques used in studying rumen bacteria}

The bacteria of the rumen, and the biochemical changes they bring about, have been widely studied in recent years. The earlier work on this subject has been reviewed by Doetsch \& Robinson (1953). It seems appropriate to begin the present review by considering briefly the techniques that have been used in these studies. They fall into six groups.

In vivo experiments. The work of Hueter, Gibbons, Shaw \& Doetsch (1958) presents an example of the use of the living ruminant for rumen studies. Carbohydrates and other materials were introduced into the rumen, and their conversion into various breakdown products was followed by analysis of samples of rumen fluid.

Artificial-rumen experiments. The artificial-rumen technique has been used by many workers, for example Burroughs and his collaborators in their investigations on cellulose digestion (Burroughs, Frank, Gerlaugh \& Bethke, 1950). The artificial rumen consists in essentials of a stoppered flask, containing the inoculum of rumen contents, buffer solution, and substrate, immersed in a constant-temperature bath. A number of refinements have been introduced by various workers, including Warner (1956), who also discussed the validity of results obtained with this kind of apparatus.

Washed-cell suspension experiments. The use of washed cells, whereby one can examine the chemical changes brought about by bacteria in conditions not allowing growth, was first applied to rumen bacteria by Sijpesteijn \& Elsden (1952). The technique has since been widely used in this field, for example by Doetsch, Robinson, Brown \& Shaw (1953). The washed-cell suspension is a very versatile biochemical tool; its use allows of an easier analysis of reaction products, and gives more clear-cut results than does the use of the bacteria suspended in their natural milieu. Hueter et al. (1958) combined their in vivo experiments referred to above with experiments on washed-cell suspensions prepared simultaneously from the rumen of the same animal. Possible reasons for the slight discrepancies between the two sets of results were discussed by the authors.

Direct microscopic observation. Direct microscopic observation of bacteria in rumen contents was carried out for many years by Baker and his collaborators. The study of the digestion of starch grains (Baker, Nasr, Morrice \& Bruce, 1950) and the atlas of rumen bacteria (Moir \& Masson, 1952) represent valuable contributions, but this method of studying rumen bacteria fell rather into disfavour when it became clear how very pleomorphic many of them can be. However, direct observation of bacteria in rumen contents has been carried out recently in a novel manner by Hobson \& Mann (1957), who prepared antibodies to pure cultures of various rumen bacteria. These antibodies, rendered fluorescent by appropriate coupling, were 
mixed with small volumes of rumen liquor. Any bacteria present serologically identical with the original culture then revealed themselves when examined in the fluorescence microscope.

Pure-culture experiments. To some bacteriologists and biochemists, experimentation with mixed cultures of bacteria has a strong suggestion of impropriety, and much effort has gone into the isolation of pure cultures of rumen bacteria. Since ruminants ingest large numbers of micro-organisms with their food, it is essential, with each culture obtained, to establish that the organism is a genuine inhabitant of the rumen, taking a part in the chemical changes occurring there, and is not merely a 'passenger' accidentally introduced from outside. The criteria by which suspected rumen bacteria may be judged are discussed by Doetsch, Howard, Mann \& Oxford (r957). The use of conventional isolation and cultural techniques has led to only moderate success in the search for cultures of significant rumen organisms. A specialized method which takes into account the peculiar requirements of many rumen bacteria for anaerobiosis, carbon dioxide and growth factors found in rumen liquor has led to striking advances in this field (Hungate, 1950).

'Enrichment-culture' experiments. Enrichment cultures in which the rumen fluid is incubated before use for some time with the substrate being investigated, under conditions allowing multiplication of cells to occur, have been little used in rumen studies.

\section{Ruminal decomposition of carbohydrates}

Experiments of the kind described above, in conjunction with analyses of the fodder constituents, have given us a broad understanding of the transformations of carbohydrates in the rumen. They are summarized in Fig. $\mathrm{I}$.

Cellulose. Cellulose is placed centrally in Fig. $\mathrm{I}$, as it is the most important of the polysaccharides undergoing breakdown in the rumen. Most of the rumen cellulolytic bacteria are extraordinarily strict in their anaerobic requirements, a few minutes' exposure to air sometimes proving lethal. It may be noted that preparations of cellulase from mixed rumen bacteria are also unstable in the absence of reducing conditions (Halliwell, 1957). The majority of the rumen cellulose-fermenting bacteria are Gram-positive or Gram-variable cocci, which may or may not form chains, or are Gram-negative rods, usually small and curved (Bryant, Small, Bouma \& Robinson, 1958) or are clostridia (Hungate, I957). Some require carbon dioxide or rumen liquor or both for growth. These cultures, when grown on cellulose, cellobiose, or glucose, give acetic, lactic and succinic acids as main end-products, with sometimes formic and butyric acids, hydrogen, carbon dioxide, ethanol and intracellular 'starch'. On the other hand, the fermentation of cellulose by mixed rumen organisms yields mainly propionic and acetic acids (Marston, 1948). The reason for this discrepancy will be apparent later.

Xylan and pentosans. Xylan occurs in the ruminant's food in close association with cellulose, and the two materials have considerable chemical similarity. The xylanand pentosan-fermenting organisms in the rumen have not received as much attention as the cellulose fermenters, but those so far investigated are almost all strictly 
Vol. I 8

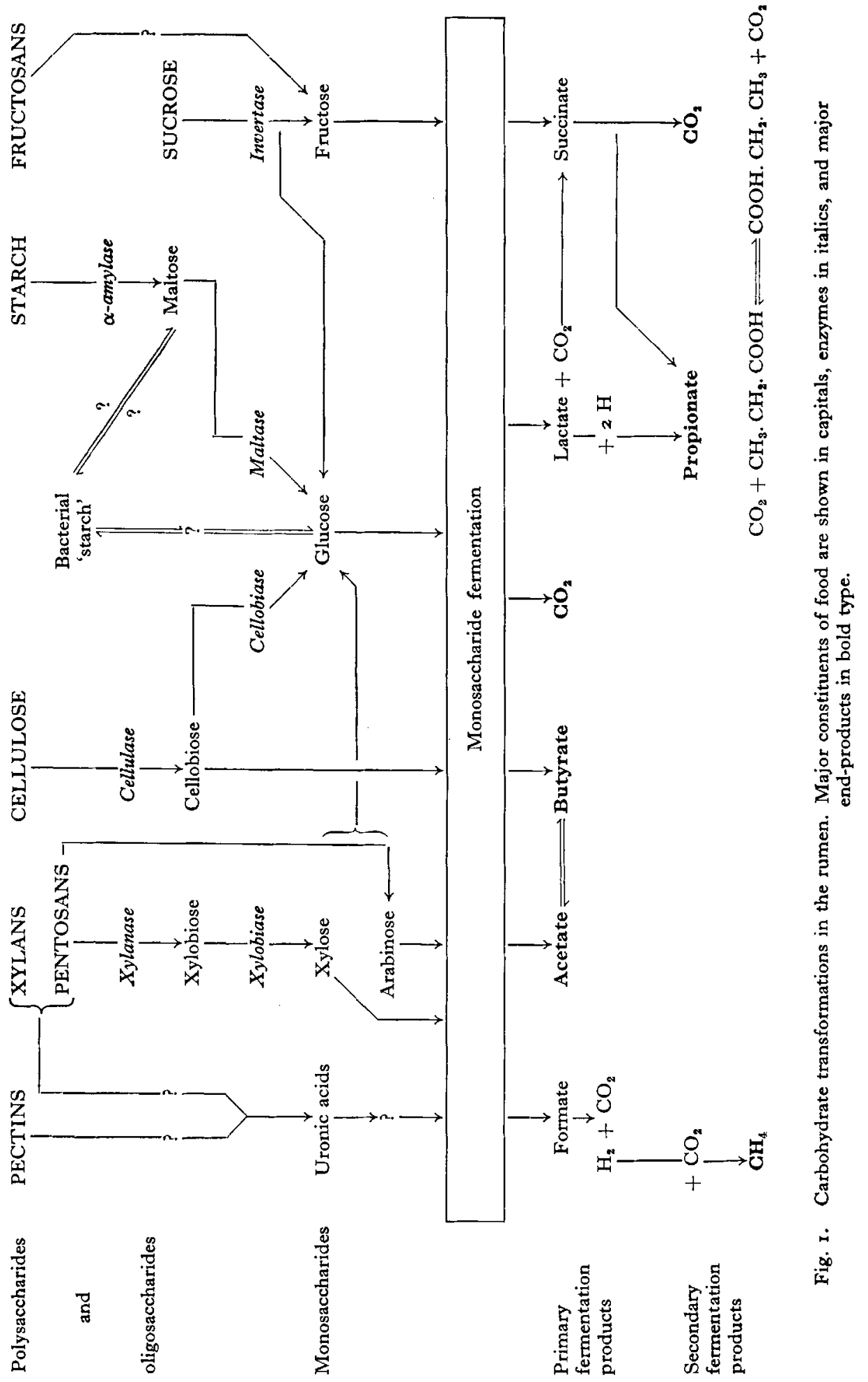


anaerobic Gram-negative curved rods, such as are described by Doetsch et al. (1957) and by Bryant \& Small (1956). Some strains can ferment both xylan and cellulose; this property is perhaps advantageous to a bacterium attacking the cellulose-xylan complex of plant fibres. Unfortunately, little is known of the products of xylan fermentation by these organisms-most analyses of fermentation products have been performed after growth on glucose or, more rarely, xylose. Fatty acids, from formic to butyric, in various proportions, seem to be the chief products (Hobson, unpublished observations). Xylan or xylose are converted by mixed rumen bacteria mainly into acetic and propionic acids (Gray \& Weller, 1958; Howard, unpublished observations).

Starch. Starch can be an important item in a ruminant's diet, especially under feeding régimes aimed at high production. Baker et al. (1950) showed the chains of an iodophilic coccus attached to decomposing starch grains in the rumen. This organism is almost certainly Streptococcus bovis which can be readily cultured from the rumen (MacPherson, 1953). Other starch fermenters isolated from the rumen more recently are mainly strictly anaerobic Gram-negative curved rods (Bryant \& Small, 1956; Bryant, Small, Bouma \& Chu, 1958). Strep. bovis yields lactic and acetic acids as chief fermentation products; the Gram-negative rods give various volatile fatty acids and occasionally succinic acid. The rumen starch-fermenting bacteria produce only $\alpha$-amylase, as far as is known at present (Hobson \& MacPherson, 1952).

Other carbohydrates. Cellulose, xylan and starch are the three most important polysaccharides in the food of ruminants, and have received most attention from the bacteriologist. Oligo- and poly-saccharides containing fructose may occur abundantly in grass and root crops. It is known that Strep. bovis will readily ferment these substances, but no doubt there are other bacteria in the rumen which would be found to do the same, if they were looked for by the appropriate methods. Similarly there are no published reports of experiments designed to discover the pectin fermenters in the rumen, although it is known that some cellulolytic bacteria can grow on pectin.

\section{Polysaccharide synthesis by rumen bacteria}

The capacity to synthesize polysaccharides, either internally as iodophilic deposits of starch-like material, or externally as capsules or layers of slime, is found in a striking diversity of rumen micro-organisms. The 'starch'-synthesizing ability of one rumen bacterium, Bacteroides amylogenes, has been investigated in some detail (Doetsch et al. 1957). A wide variety of hexoses, pentoses, oligo- and poly-saccharides will serve as starch precursors. The starch is clearly a food reserve, as it disappears when the living cells are incubated in the absence of external carbohydrate. In contrast to the starch-like nature of the internal polysaccharides of rumen bacteria, the capsular substances are, as far as is known, not wholly glucosidic. That from a strain of Strep. bovis, for example, is built up mainly from galactose, rhamnose and a uronic acid (Hobson \& MacPherson, 1954). Other strains of this organism also produce a dextran (Bailey, 1959). Apart from the presence of sucrose, the conditions necessary for the production of the dextran in culture are strikingly similar to those 
found in the rumen, i.e. a high concentration of carbon dioxide and the presence of $B$ vitamins and acetate (Oxford, $195^{8}$ ).

The 'starch'-synthesizing ability found in so many rumen micro-organisms prompts the question, does the material leaving the rumen yield to the animal any significant amount of digestible carbohydrate of microbial origin? This point cannot be regarded as settled yet, but the experiments of Heald (I95I) and Weller \& Gray (I954) with hay-fed sheep suggest a negative answer.

\section{Secondary reactions in the rumen}

None of the substances mentioned above as end-products of metabolism of pure cultures of rumen bacteria is metabolically inert in the rumen. Experiments with whole rumen fluid and with pure cultures have demonstrated the occurrence of a number of reactions, which are summarized in the lower part of Fig. I. Lactates put into the rumen are quickly decomposed, yielding mainly propionic acid (Hueter, Shaw \& Doetsch, 1956). A single experiment with radioactive lactate suggested that most of this conversion took place by direct reduction, but that some propionic acid was formed through succinic acid, by carbon-dioxide fixation (Pazur, Shuey $8 x$ Georgi, I958). Many lactate-fermenting bacteria have been isolated from the rumen, and most of them yield propionic acid as principal product. Some use the 'reduction' route (Ladd, 1959) others the 'fixation' route (Johns, I95I).

Succinic acid is rapidly metabolized in the rumen, being decarboxylated to propionic acid. The lactate-fermenting bacteria which form propionic acid by the 'fixation' route are usually able to decarboxylate added succinate.

Recent experiments with radioactive substrates (R. J. Pennington \& D. B. Mukherjee, unpublished observations) show propionic acid in the rumen to be in dynamic equilibrium with carbon dioxide and succinic acid or a derivative. Half the radioactivity of $\mathrm{C}_{2} \mathrm{H}_{5}{ }^{14} \mathrm{COOH}$ added to rumen liquor in vitro appeared as $\mathrm{CO}_{2}$ after incubation for $3 \mathrm{~h}$, and conversely $\mathrm{NaH}^{14} \mathrm{CO}_{3}$ gave rise to labelled propionic acid. Similar experiments have shown that in the rumen acetic and butyric acids are interconvertible. Australian workers found the equilibrium to lie on the butyricacid side (Gray, Pilgrim, Rodda \& Weller, 1952), but under the conditions used by Pennington \& Mukherjee at the Rowett Research Institute it appeared to be on the acetic-acid side.

Formic acid is rapidly decomposed in the rumen into carbon dioxide and hydrogen. The hydrogen formed by this, and perhaps other, reactions, undergoes yet another transformation, in which carbon dioxide is reduced to methane (Carroll \& Hungate, 1955). The rumen seems to contain a population of 'methane bacteria', similar in their main properties to the free-living forms. The methane formed under normal conditions is about five rumen volumes daily.

\section{Conclusion}

Of a number of problems in this field which require further investigation, two may be mentioned in concluding this review. The first is to assess the significance of polysaccharide synthesis by rumen bacteria (a) for the individual bacterial species 
(b) for the rumen as a whole, and (c) for the host animal. The second is to devise cultural methods for isolating the many micro-organisms that can be seen in the rumen but have hitherto tantalizingly evaded the bacteriologist.

\section{REFERENCES}

Bailey, R. W. (1959). Biochem. F. 71, 23.

Baker, F., Nasr, H., Morrice, F. \& Bruce, J. (1950). F. Path. Bact. 62, 6r7.

Bryant, M. P. \& Small, N. (1956). \%. Bact. 72, I6.

Bryant, M. P., Small, N., Bouma, C. \& Chu, H. (1958). F. Bact. 76, 15.

Bryant, M. P., Small, N., Bouma, C. \& Robinson, I. M. (1958). F. Bact. 76, 529.

Burroughs, W., Frank, N. A., Gerlaugh, P. \& Bethke, R. M. (1950). F. Nutr. 40, 9.

Carroll, E. J. \& Hungate, R. E. (1955). Arch. Biochem. Biophys. 56, 525.

Doetsch, R. N., Howard, B. H., Mann, S. O. \& Oxford, A. E. (1957). F. gen. Microbiol. 16, $5_{5} 6$.

Doetsch, R. N. \& Robinson, R. Q. (1953). F. Dairy Sci. 36, 1 I 5.

Doetsch, R. N., Robinson, R. Q., Brown, R. E. \& Shaw, J. C. (1953). F. Dairy Sci. 36, 825.

Gray, F. V., Pilgrim, A. F., Rodda, H. J. \& Weller, R. A. (1952). Э. exp. Biol. 29, 57.

Gray, F. V. \& Weller, R. A. (1958). Aust. F. agric. Res. 9, 797.

Halliwell, G. (1957). F. gen. Microbiol. 17, 166.

Heald, P. J. (195I). Brit. F. Nutr. 5, 84.

Hobson, P. N. \& MacPherson, M. (1952). Biochem. F. 52, 67 I.

Hobson, P. N. \& MacPherson, M. J. (1954). Biochem. F. 57, 145.

Hobson, P. N. \& Mann, S. O. (1957). Y. gen. Microbiol. 16, 463 .

Hueter, F. G., Gibbons, R. J., Shaw, J. C. \& Doetsch, R. N. (1958). F. Dairy Sci. 41, 65 I.

Hueter, F. G., Shaw, J. C. \& Doetsch, R. N. (1956). F. Dairy Sci. 39, 1430.

Hungate, R. E. (1950). Bact. Rev. r4, I.

Hungate, R. E. (I957). Canad. F. Microbiol. 3, 289 .

Johns, A. T. (I95I). F. gen. Microbiol. 5, 326.

Ladd, J. N. (1959). Biochem. F. 7r, 16.

MacPherson, M. (1953). F. Path. Bact. 66, 95.

Marston, H. R. (1948). Biochem. F. 42, 564 .

Moir, R. J. \& Masson, M. J. (1952). F. Path. Bact. 64, 343.

Oxford, A. E. (1958). F. gen. Microbiol. I9, 6 I7.

Pazur, J. H., Shuey, E. W. \& Georgi, C. E. (1958). Arch. Biochem. Biophys. 77, 387.

Sijpesteijn, A. K. \& Elsden, S. R. (1952). Biochem. F. 52, 4I.

Warner, A. C. I. (1956). 7. gen. Microbiol. I4, 733.

Weller, R. A. \& Gray, F. V. (1954). F. exp. Biol. 31, 4 o.

\section{Protein utilization by the dairy cow}

\section{By M. J. HeaD*, National Institute for Research in Dairying, Shinfield, Reading}

The content of true protein, or the amino-acid composition of the protein, in a nitrogenous feed is less important to a dairy cow than to a single-stomached animal. Johnson, Hamilton, Mitchell \& Robinson (1942) have, in fact, suggested that the biological value for ruminants of all nitrogenous feeds is about 60 , but Williams \& Moir (I95I) have since found that this generalization is not correct. The suggestion was based on the knowledge that food protein is fermented by the rumen microorganisms and that the bodies of these organisms provide the host with much of its protein for subsequent enzymic digestion, which microbial protein has a relatively high value and constant composition.

\footnotetext{
* Present address: Spillers Limited, Nutrition Research Laboratories, Middle Aston, Oxon.
} 